\title{
Feeding guilds of western Mediterranean demersal fish and crustaceans: an analysis based on a spring survey*
}

\author{
JOAN E. CARTES ${ }^{1}$, PERE ABELLÓ ${ }^{1}$, DOMÈNEC LLORIS ${ }^{1}$, AINA CARBONELL $^{2}$, \\ PEDRO TORRES ${ }^{3}$, FRANCESC MAYNOU ${ }^{1}$ and LUIS GIL DE SOLA ${ }^{3}$ \\ ${ }^{1}$ Institut de Ciències del Mar, CMIMA-CSIC, Passeig Marítim de la Barceloneta 37-49, 08003 Barcelona, Spain. \\ E-mail: jcartes@icm.csic.es \\ ${ }^{2}$ Centre Oceanogràfic de les Balears (I.E.O.), Moll de Ponent s/n, Ap. 291, 07080 Palma de Mallorca, Spain. \\ ${ }^{3}$ Centro Oceanográfico de Málaga (I.E.O.), Puerto pesquero s/n, 29640 Fuengirola (Málaga), Spain.
}

\begin{abstract}
SUMMARY: The MEDITS-99 sampling was performed along all the Iberian Peninsula coasts of the western Mediterranean (from the Alborán Sea to Cape Creus) in a space-scale of $1000 \mathrm{Km} \mathrm{N}-\mathrm{S}$, at depths ranging between 27-790 m. Fish and decapod crustaceans were dominant in the megafaunal compartment sampled by trawling. Based on both the fish and the decapod crustacean compositions, a comparison of trophic guilds has been attempted, with fish and decapods classified as: 1) migrator macroplankton feeders (mM), 2) non-migrator macroplankton feeders (nmM), 3) nektobenthos-suprabenthos feeders (NS), 4) epibenthos feeders (Epib), 5) large detritus-scavengers (Sca), 6) infaunal feeders (Inf), 7) deposit feeders (Dep) and 8) small detritivorous feeders (Det). Multivariate techniques showed the following differences in the trophodynamics of the megafaunal assemblages along the coasts of the Iberian Peninsula: 1) crustaceans (mainly decapods) have different trophic structures on the shelf and on the slope; 2) on the slope, fish exhibited more clear changes as a function of the geographical gradient than crustaceans; and 3) trophodynamics of bathyal fish showed some geographic variations between the Alborán Sea, the Catalano-Balearic Basin, and the Algerian Basin (Vera Gulf and Alicante sectors), with a progressive north-south increase in planktophagous species.
\end{abstract}

Key words: feeding guilds, demersal fish, decapod crustaceans, western Mediterranean, trawl survey, Mediterranean.

\section{INTRODUCTION}

Demersal fisheries along the Mediterranean coasts have been directed at a variety of resources, including fish, decapod crustaceans and cephalopods (Bertrand and Relini, 2000). Trawling is the main fishing activity below the $50 \mathrm{~m}$ isobath, with an important increase in deep-water fisheries (deeper than $150 \mathrm{~m}$ ) which have been operating for a long time (Bas et al., 1955) on important target

\footnotetext{
*Received November 7, 2000. Accepted April 2, 2001
}

species such as the shrimps Parapenaeus longirostris and Aristeus antennatus, the Norway lobster Nephrops norvegicus, or fish species such as hake Merluccius merluccius or Phycis blennoides. These fisheries can reach down to $800 \mathrm{~m}$.

During recent years, sustainable use of natural resources has been increasingly enhanced. Deepwater communities have received increasing attention at a global scale because of the interest in new fishing grounds and fisheries at bathyal depths (Hopper, 1994; Merrett and Haedrich, 1997). However, deep-water ecosystems have lower energetical 
turnovers than shallow-water or littoral systems and their carrying capacity is expected to be lower. Since most of the target species are slow growing, overexploitation can be detected in deep-sea fisheries only after some years or decades after the beginning of a fishery (Atkinson, 1994; Bowering and Brodie, 1994; Koslow, 1997).

In addition to indices such as abundance, or harvest-induced mortality (Hutchings and Myers, 1994), to quantify changes and the impact in the carrying capacity of a system, trophodynamic aspects can be studied (Petersen and Curtis, 1980; Robinson and Ware, 1994; Christensen, 1995, among others). Trophodynamic studies constitute the base of massbalance models (i.e ECOPATH models), which have increasingly been considered for the study and management of marine ecosystems (Robinson and Ware, 1994; Wolff, 1994; Christensen, 1995; Pauly and Christensen, 1995). In practice, however, great difficulties exist in developing such models in deepwater systems, because only scarce data have been published on important quantitative aspects such as secondary production (Cartes and Sorbe, 1999; Cartes et al., 2000), and daily rations (Maynou and Cartes, 1997; 1998; Cartes and Maynou, 2001), with only some preliminary trophic balances constructed for the mid-slope depths (Cartes and Maynou, 1998). Trophodynamic studies in deep-sea systems have often focused on species of commercial interest (Macpherson, 1985; Bulman and Koslow 1992, Maynou and Cartes 1997), whereas by-catches and studies on the lowest trophic levels, i.e. those compartments that sustain the trophic webs and fisheries, have received, in general, little attention (Christensen, 1995; Cartes and Maynou, 2001).

Even in stable environments such as the deep sea, local changes in the food supply and productivity may affect the trophic structure and dynamics of marine ecosystems, which are reflected for instance in the zonation pattern of species with depth (Haedrich and Merrett, 1990; Maynou and Cartes, 2000). It is, thus, often inappropriate to extrapolate the results obtained in a concrete area to a wider geographic scale. As an alternative to the lack of the integral sampling of trophic webs, comparative studies on trophic guilds composition with depth and geographic gradients can give information on changes in the ecosystem structure and functioning because changes in feeding guilds composition may reflect differences in the structure of trophic webs and in the energy flow. Thus, Koslow (1997) defined a distinct guild of fish species that aggregate around seamounts in Australian waters where Hoplostethus atlanticus is the main target species. This guild is characterized by high levels of pelagic-food consumption and strong swimming performance. Recently, important differences were evidenced between the trophic guilds of bathyal crustaceans inhabiting the Catalan Sea and the SW Balearic Islands, with dominance of non-migrator macroplankton feeders (mainly composed by Plesionika spp. shrimps) in the SW Balearic Islands, and higher abundance of infaunal and deposit feeders in the Catalan Sea area (Cartes et al., 2000; Maynou and Cartes, 2000). Plankton and benthos may, thus, support distinctly trophic chains in relatively neighbouring areas. Our objective in this study is to compare and identify zones with different food-web structures (i.e. more or less supported by plankton or benthos productivity), along the wide geographic area covered in MEDITS cruises in a space-scale of $1000 \mathrm{Km}$. Plankton and benthos are two contrasting food sources in marine environments as evidenced, for instance, from results obtained using $\delta^{13} \mathrm{C}$ stable isotope analysis (Jennings et al., 1997).

\section{MATERIAL AND METHODS}

The MEDITS-ES99 cruise (May-June 1999) comprised a total of 116 trawls performed between 27 and $790 \mathrm{~m}$ depth along the coasts of the Iberian Peninsula (western Mediterranean) from the Straits of Gibraltar to Cape Creus (Fig.1). Fish and crustaceans (mainly megabenthic decapods) were sampled with an especially designed bottom trawl (cf. Bertrand et al., 2000), equipped with two doors, two trawl warps, and a $100 \mathrm{~m}$ long bridle, with an horizontal aperture of $c a .18 \mathrm{~m}$ and a vertical height of ca. $2 \mathrm{~m}$. The codend mesh size was $10 \mathrm{~mm}$. In previous studies on MEDITS cruises (Abelló et al., 2000, 2002; Carbonell et al., 2000), this area was divided into eight geographical sectors: (1) Western Alborán Sea (WALB), from Gibraltar to Nerja; (2) Eastern Alborán Sea (EALB), from Nerja to Cape Gata; (3) Vera Gulf (VERA), from Cape Gata to Cape Palos; (4) Alacant region (ALAC), from Cape Gata to Cape La Nao; (5) Valencia (VALE), from Cape La Nao to Castelló; (6) Ebro delta region (DELT), from Castelló to Tarragona; (7) Northern Catalonia (NCAT), from Tarragona to Cape Creus, and (8) Eivissa island (EIV) (Fig. 1). We adopted this same nomenclature to the $a$ posteriori labelling of our sampling stations in the multivariate analysis results. 


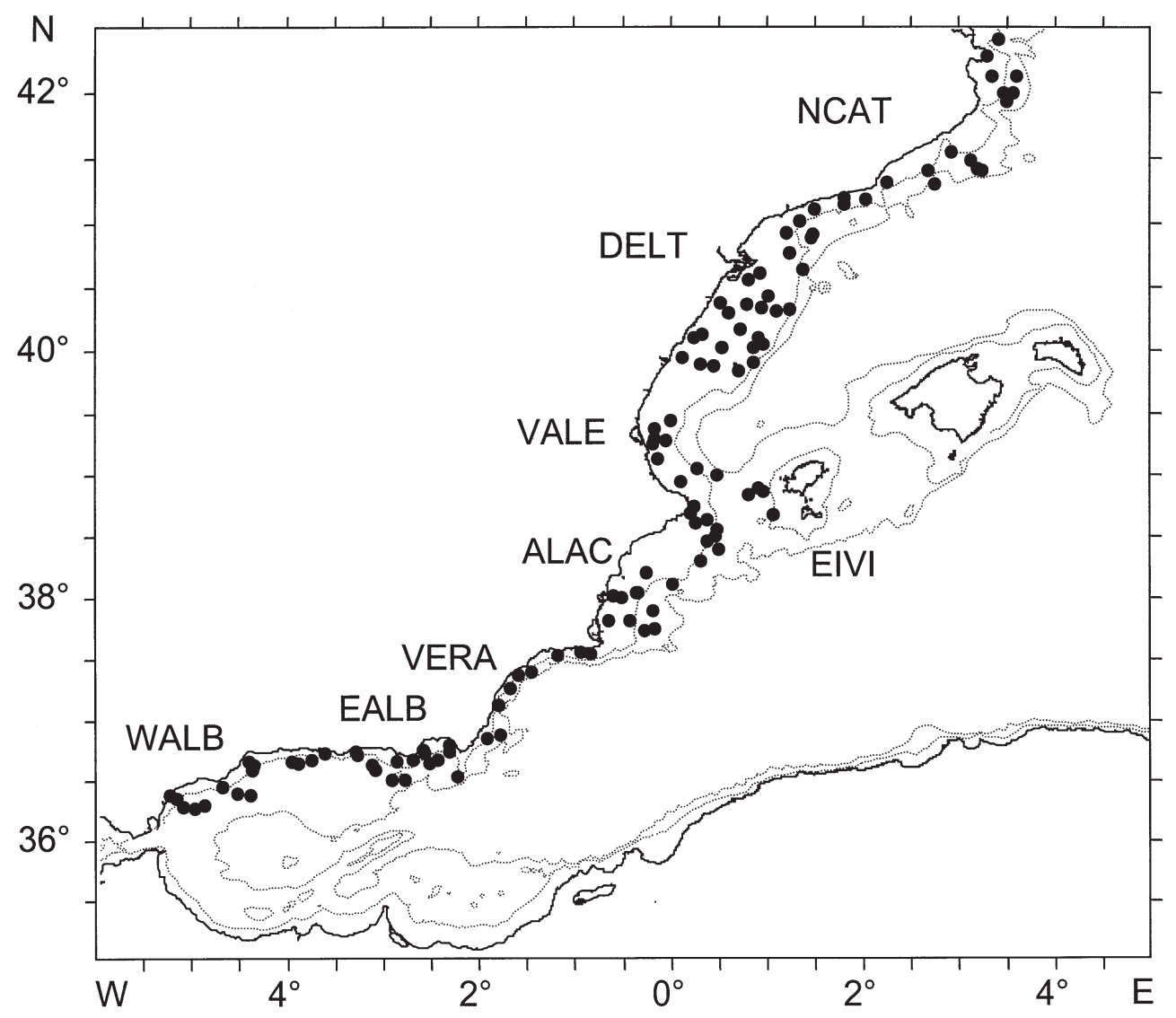

FIG. 1. - Map of the study area off the Mediterranean Iberian Peninsula, showing the trawl location and the sectors in which the coast was divided.

Feeding guilds were established for fish and crustaceans. Both fish and crustacean species were classified within the following feeding groups (or guilds): 1) migrator macroplankton feeders $(\mathrm{mM})$, 2) non-migrator macroplankton feeders $(\mathrm{nmM}), 3)$ nektobenthos-suprabenthos (=vagile fauna) feeders (NS), 4) epibenthos (= non vagile fauna) feeders (Epib), 5) large detritivorous-scavengers (Sca), 6) infaunal feeders (Inf), 7) deposit feeders (Dep), and 8) small detritivorous feeders (Det). Guilds 1, 2, 4 and 6 are both common to fish and decapods, guild 3 is described only for fish, while guilds 5, 7 (deposit feeders) and 8 (small detritivorous feeders) only existed among crustaceans (see Table 1).

Trophic guilds have been already defined in previous studies both among fish (e.g. Gartner et al., 1997) and Mediterranean decapod crustaceans (Cartes, 1998; Maynou and Cartes, 2000). In our study, guilds are defined based on detailed information both on crustaceans and on bathyal-fish diets in the western Mediterranean (Cartes, 1991; 1994; 1998; Cartes and Abelló, 1992; Macpherson, 1977, 1979; Carrasson and Matallanas, 1990; Carrasson et al., 1992; Carrasson, 1994; Stefanescu and Cartes, 1992 and references cited therein). In addition, summary diets of a total of seven decapod species, not previously documented, have been included in Table 2. The established guilds show the dependence of the fish/crustacean ratio on the exploitation of benthic or pelagic food resources which may in turn indicate local changes in the trophic structure of trophic webs. It is also well known that, even in a relatively stable environment such as the deep sea, fish have seasonal changes in their diet. The temporal effect is minimized in our study given the practically simultaneous sampling of an extensive area covered in the MEDITS cruise. We also assume that feeding preferences of species did not vary along the geographical gradient covered in the MEDITS cruise (see discussion below).

Crustacean feeding guilds were studied throughout the bathymetric range sampled. Fish, however, were only considered at bathyal depths, due to: (i) the gaps existing for dietary studies in an important proportion of shelf fish in the area; and (ii) we considered it inappropriate to extrapolate the results of 
TABLE 1. - Classification of the most abundant species (crustaceans and bathyal fish) in trophic guilds: 1) migrator macroplankton feeders $(\mathrm{mM}), 2)$ non-migrator macroplankton feeders (nmM), 3) nektobenthos-suprabenthos feeders (NS), 4) epibenthos feeders (Epib), 5) large detritus-scavengers (Sca), 6) infaunal feeders (Inf), 7) deposit feeders (Dep), 8) small detritivorous feeders (Det). Sources: (1) Dietary information obtained from references included in the reference list or in the present study (see Table 2); (2) from other references not included in the reference list; (3) from general information obtained from the Fishbase dataset (http://ibs.uel.ac.uk/fishbase/), and from Withehead et al. (1986); (4) own unpublished data; and (5) diet assumed from neighbouring species.

\begin{tabular}{|c|c|c|c|c|c|}
\hline \multicolumn{2}{|l|}{ Fish } & \multirow{2}{*}{$\begin{array}{r}\text { source } \\
\text { (2) }\end{array}$} & \multicolumn{2}{|l|}{ Crustaceans } & ource \\
\hline Myctophum punctatum & $\mathrm{mM}$ & & Gennadas elegans & $\mathrm{mM}$ & (1) \\
\hline Lampanyctus crocodilus & $\mathrm{mM}$ & (1) & Pasiphaea multidentata & $\mathrm{mM}$ & (1) \\
\hline Argyropelecus hemigyтпиs & $\mathrm{mM}$ & (2) & Pasiphaea sivado & $\mathrm{mM}$ & (1) \\
\hline Symbolophorus veranyi & $\mathrm{mM}$ & (2) & Sergestes arcticus & $\mathrm{mM}$ & (2) \\
\hline Notoscopelus elongatus & $\mathrm{mM}$ & (2) & Sergestes arachnipodus & $\mathrm{mM}$ & (4) \\
\hline Benthosema glaciale & $\mathrm{mM}$ & (2) & Sergia robusta & $\mathrm{mM}$ & (1) \\
\hline Stomias boa & $\mathrm{mM}$ & (2) & Plesionika narval & $\mathrm{nmM}$ & (4) \\
\hline Maurolicus mиelleri & $\mathrm{mM}$ & (2) & Plesionika acanthonotus & $\mathrm{nmM}$ & (1) \\
\hline Ceratoscopelus maderensis & $\mathrm{mM}$ & (3) & Plesionika antigai & $\mathrm{nmM}$ & (5) \\
\hline Mora moro & $\mathrm{nmM}$ & (1) & Plesionika edwardsi & $\mathrm{nmM}$ & (1) \\
\hline Etmopterus spinax & $\mathrm{nmM}$ & (1) & Plesionika gigliolii & $\mathrm{nmM}$ & (1) \\
\hline Capros aper & $\mathrm{nmM}$ & (1) & Plesionika heterocarpus & $\mathrm{nmM}$ & (1) \\
\hline Scyliorhinus canicula & $\mathrm{nmM}$ & (1) & Plesionika martia & $\mathrm{nmM}$ & (1) \\
\hline Alepocephalus rostratus & $\mathrm{nmM}$ & (1) & Natatolana borealis & Sca & (4) \\
\hline Micromesistius poutassou & $\mathrm{nmM}$ & (1) & Munida intermedia & Sca & (1) \\
\hline Macroramphosus scolopax & $\mathrm{nmM}$ & (1) & Munida rutllanti & Sca & (4) \\
\hline Epigonus denticulatus & $\mathrm{nmM}$ & (1) & Munida tenuimana & Sca & (1) \\
\hline Hoplostethus mediterraneus & $\mathrm{nmM}$ & (1) & Pagurus alatus & Sca & (1) \\
\hline Gadiculus argenteus & $\mathrm{nmM}$ & (1) & Pagurus excavatus & Sca & (1) \\
\hline Galeus melastomus & $\mathrm{nmM}$ & (1) & Pagurus prideaux & Sca & (5) \\
\hline Lepidopus caudatus & $\mathrm{nmM}$ & (1) & Dardanus arrosor & Sca & (5) \\
\hline Trisopterus minutus capelanus & NS & (1) & Polycheles typhlops & Epib & (1) \\
\hline Ophichtus rufus & NS & (3) & Bathynectes maravigna & Epib & (5) \\
\hline Lophius budegassa & NS & (1) & Ligur ensiferus & Epib & (1) \\
\hline Molva dipterygia & NS & (1) & Liocarcinus depurator & Epib & (2) \\
\hline Conger conger & NS & (1) & Macropipus tuberculatus & Epib & (2) \\
\hline Nezumia aequalis & NS & (1) & Polybius henslowi & Epib & (3) \\
\hline Serranus hepatus & NS & (3) & Squilla mantis & Epib & (3) \\
\hline Hymenocephalus italicus & NS & (1) & Rissoides pallidus & Epib & (5) \\
\hline Merluccius merluccius & NS & (1) & Aristeus antennatus & Inf & (1) \\
\hline Chorophthalmus agassizi & NS & (3) & Chlorotocus crassicornis & Inf & (1) \\
\hline Pagellus acarne & NS & (3) & Calappa granulata & Inf & (1) \\
\hline Notacanthus bonapartei & Epib & (1) & Geryon longipes & Inf & (2) \\
\hline Helicolenus dactylopterus & Epib & (1) & Goneplax rhomboides & Inf & (4) \\
\hline Symphurus ligulatus & Inf & (1) & Medorippe lanata & Inf & (5) \\
\hline Antonogadus megalokinodon & Inf & (1) & Monodaeus couchii & Inf & (2) \\
\hline Arnoglossus laterna & Inf & (3) & Nephrops norvegicus & Inf & (1) \\
\hline Arnoglossus rueppelli & Inf & (3) & Parapenaeus longirostris & Inf & (1) \\
\hline Phycis blennoides & Inf & (1) & Philocheras echinulatus & Inf & (1) \\
\hline Lepidorhombus boscii & $\operatorname{Inf}$ & (1) & Pontocaris cataphracta & Inf & (5) \\
\hline Coelorhynchus coelorhynchus & $\operatorname{Inf}$ & (1) & Pontocaris lacazei & Inf & (1) \\
\hline Chimaera monstrosa & Inf & (1) & Pontophilus spinosus & Inf & (1) \\
\hline Trachyrhynchus trachyrhynchus & Inf & (1) & Processa canaliculata & Inf & (1) \\
\hline Symphurus nigrescens & Inf & (1) & Processa nouveli & Inf & (1) \\
\hline & & & Solenocera membranacea & Inf & (1) \\
\hline & & & Atelecyclus rotundatus & Inf & (5) \\
\hline & & & Calocaris macandreae & Dep & (1) \\
\hline & & & Alpheus glaber & Dep & (4) \\
\hline & & & Meganyctiphanes norvegica & Det & (4) \\
\hline & & & Pandalina profunda & Det & (4) \\
\hline & & & Lophogaster typicus & Det & (4) \\
\hline
\end{tabular}

dietary studies made in other areas, in view of the high habitat and food-source heterogeneity reported for shelf-living fish (see for instance Jennings et al., 1997). Bathyal hauls for the fish-guilds study were selected after a cluster analysis was perfomed on the matrix of species composition. This matrix was constructed based on 185,383 specimens pertaining to 114 species captured in116 trawls. Species occurring with $<5$ specimens were removed from the data matrix and the captures were standardized to 1-h of trawling. The Pearson correlation coefficient (1-r) was used as distance and the UPGMA as the algorythm of aggregation (Statistica 4.5), after log transformation of values to linearize data. The cluster analysis (Fig. 2) exhibited a major fish-faunistic discontinuity situated around 325-341 m, separating the group of bathyal trawls (down to $790 \mathrm{~m}$ ) from the group including the shelf-fish assemblages (27 
Table 2.- Diets of different decapod species dominant in the present survey. (n): number of individuals analyzed; TG: trophic guild assigned. (*) from MEDITS-99 cruise.

\begin{tabular}{|c|c|c|c|c|}
\hline Species & prey items & $\mathrm{n}$ & TG & observations \\
\hline Gennadas elegans & calanoids $\quad .$. & 7 & $\mathrm{mM}$ & \\
\hline $\begin{array}{l}\text { Sergia robusta } \\
\text { Plesionika gigliolii }\end{array}$ & $\begin{array}{l}\text { calanoids, euphausiids, } \\
\text { chaetognaths. } \\
\text { euphausiids, Sergestes sp., }\end{array}$ & 18 & $\mathrm{mM}$ & R1 cruise: April 1990 \\
\hline & siphonophora & 16 & $\mathrm{nmM}$ & R3 cruise: March 1991 \\
\hline Plesionika heterocarpus* & euphausiids & 9 & $\mathrm{nmM}$ & euphausiids: $100 \%$ volume \\
\hline Ligur ensiferus & $\begin{array}{l}\text { Gammaridean amphipods, } \\
\text { echinoderms }\end{array}$ & 40 & Epib & R2 cruise: December 1991 \\
\hline $\begin{array}{l}\text { Chlorotocus crassicornis* } \\
\text { Calappa granulata* }\end{array}$ & $\begin{array}{l}\text { euphausiids, molluscs } \\
\text { bivalves, foraminiferans }\end{array}$ & $\begin{array}{r}15 \\
3\end{array}$ & $\underset{\mathrm{Inf}}{\mathrm{nmM}}$ & probably pelagic molluscs \\
\hline
\end{tabular}

to $325-341 \mathrm{~m})$. Within this last group, a secondary homogeneous cluster was identified containing trawls between 240 to $341 \mathrm{~m}$. As a consequence, those trawls exceeding $300 \mathrm{~m}$ depth were selected in this study for trophic guild analysis, thus avoiding the excess of heterogeneity in the samples. Under this criterion, a total of 18,533 specimens pertaining to 53 bathyal species captured in 42 trawls were selected.

Once feeding groups were established, clustering methods were applied (1-r / UPGMA) to the crustacean and fish matrix feeding groups. For crustaceans, species occurring with $<5$ specimens, and trawls where $<8$ individuals were captured were removed from the data matrix, resulting in a total of
97 valid trawls. Cluster analysis showed two main assemblages separating the continental shelf and the slope samples (see below). Multidimensional scaling (MDS) techniques were applied to the similarity matrix generated by clustering (1-r measure) to obtain a 2-dimensional representation of the trophic guild composition of: 1) crustaceans from the continental shelf; 2) bathyal fish from those trawls exceeding 300 $m$ depth (see above); and 3) bathyal crustaceans, which were only considered from trawls exceeding $300 \mathrm{~m}$ to give a more reliable comparison between fish and crustaceans. The objective was to explore other factors than depth (especially geographical variations) which may contribute to the ordination of trophic guilds along interpretable dimensions.

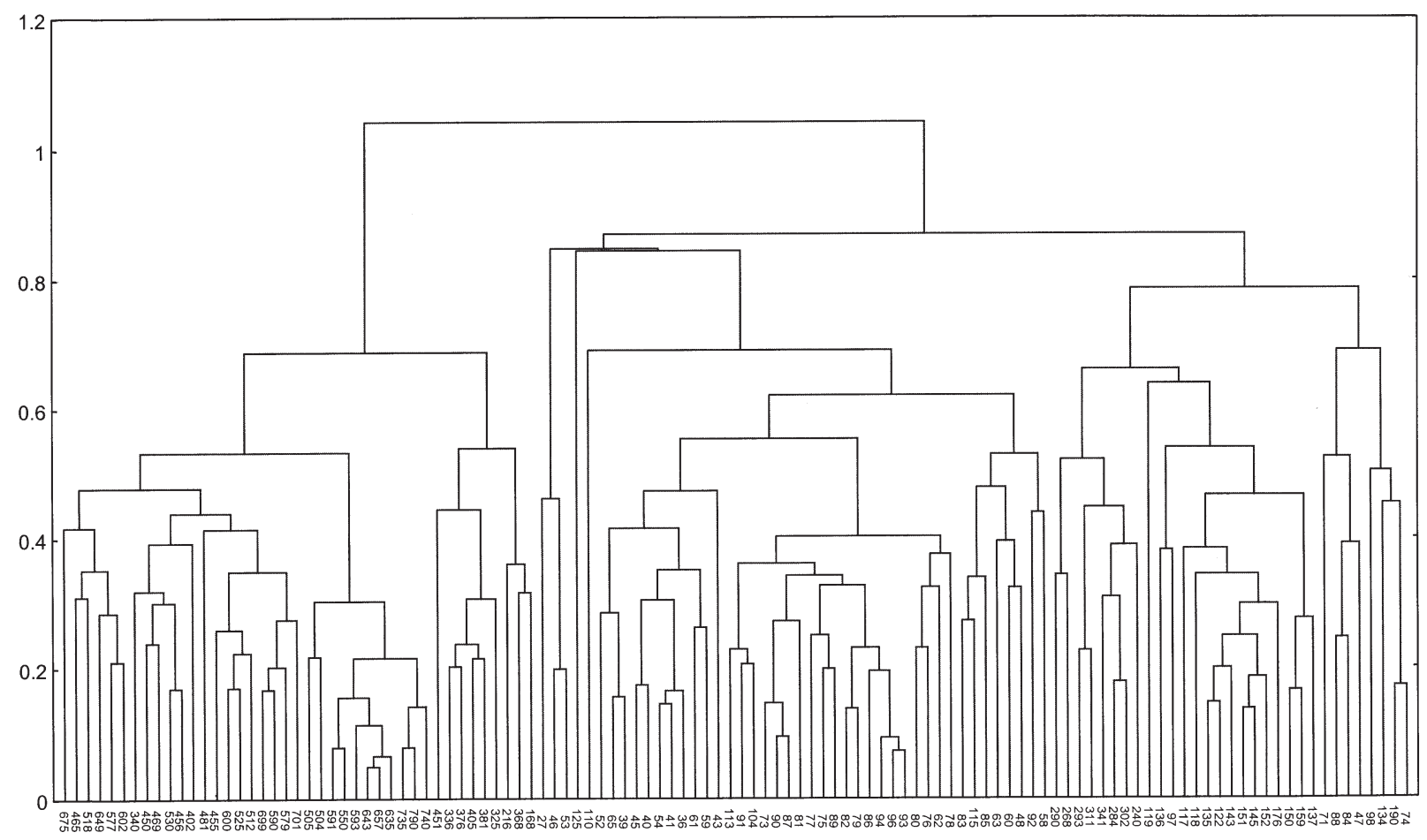

FIG. 2. - Cluster analysis perfomed on the matrix of fish species composition standardized to $1 \mathrm{~h}$ of trawling (1-r; UPGMA). Codes of the samples indicate mean depth of the haul. 


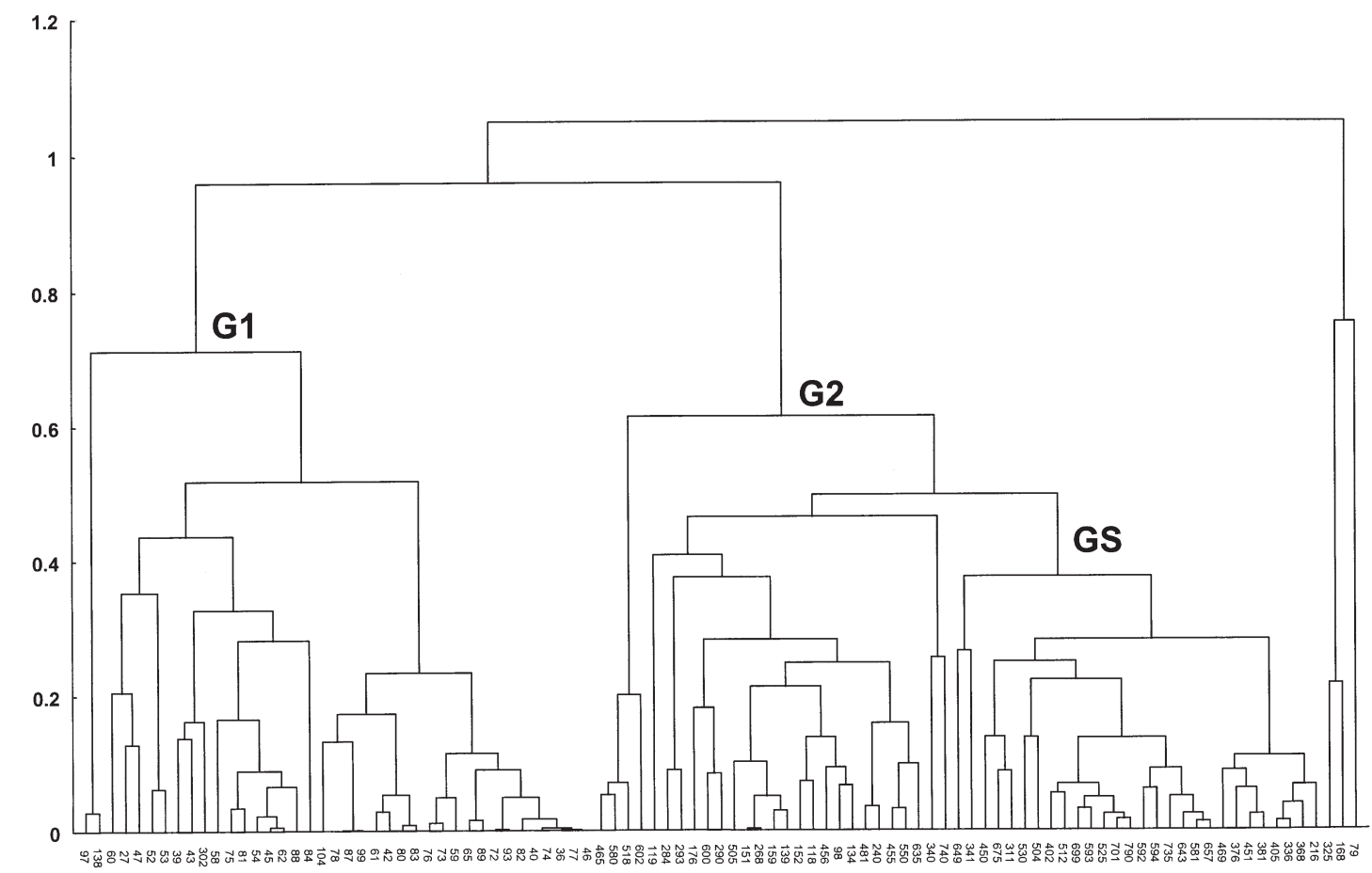

FIG. 3. - Cluster for crustacean trophic guilds showing the shelf (G1) and the slope (G2) groups. 1-r (Pearson correlation) was the distance used and UPGMA was the aggregation algorithm. Codes of the samples indicate mean depth of the haul.

\section{RESULTS}

Qualitative data on the diet of seven decapod custaceans have been obtained based on stomach content analysis. Species were included in their corresponding feeding guild based on this information (Table 2).

Cluster analysis revealed a clear separation in trophic-guild composition among crustaceans (mainly decapods) collected, with low r (of $c a$. 0) separating the two main groups of samples (Fig. 3). These groups were clearly formed as a function of depth, revealing quite different trophic composition and probably trophodynamics on the continental shelf and on the slope: G1 comprised hauls performed between 27 and $138 \mathrm{~m}$ (excluding a single haul performed at $302 \mathrm{~m}$ ); and $\mathrm{G} 2$ comprised hauls between 118 and $790 \mathrm{~m}$ depth (with the single exception of a haul performed at $98 \mathrm{~m}$ ). Within G2, further depth separations existed with a deeper homogeneous group which was almost exclusively composed of trawlings performed between 311 and $790 \mathrm{~m}$ (Fig. 3; $\mathrm{G}_{\mathrm{s}}$ ). Similar results, at least concerning the identification of $\mathrm{G} 1$ and G2 groups, were attained using the Euclidean distance and Ward algorythm (not included).

We tried to identifiy some other gradient (e.g. geographical) within the shelf (trawling depths between 27 and $118 \mathrm{~m}$; 44 samples) and the slope (> $300 \mathrm{~m}$ depth; 42 samples) groups: Among crustaceans, MDS based on the 1-r similarity matrix did not reveal any clear subgrouping, neither within the shelf nor the slope groups. The shelf samples were ordered (stress $=0.154$ ) in a 2-dimensional space, as in the case of slope samples ( shelf samples were not grouped as a function of any geographical gradient (Fig. 4a). Shelf samples from the area around the Ebro river delta (DELT sector) and the Alborán Sea occupied the extremes of the gradient in the MDS plot, which suggests that some ordination probably takes place in the continental shelf as a function of small-scale changes in the sediment characteristics (a non-measured parameter in the present study). Among the 42 slope samples, six samples corresponding to the Catalan Sea area (NCAT sector) showed some separation. Also, certain gradient of north-south ordination can be observed along the first axis (factor 1), with some northern (NCAT), and southern (WALB) samples placed in the extremes of the axis (Fig. 4b). However the rest of bathyal samples did not show any ordination.

Among bathyal fish, both the clustering and the MDS, based also on the 1-r similarity matrix, gave some separation of samples. Cluster analysis (Fig. 5) revealed a first homogeneous group of seven trawls 

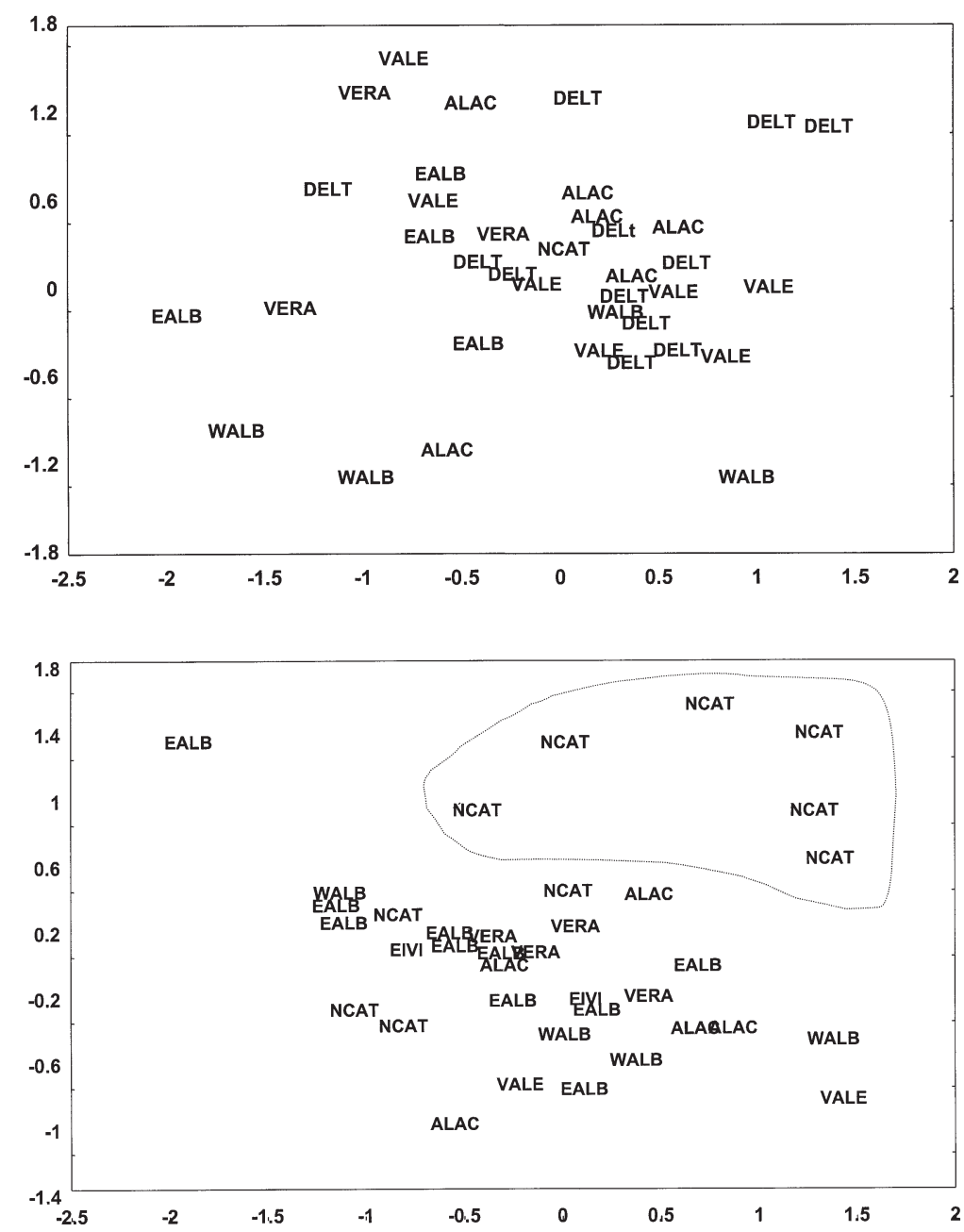

FIG. 4. - MDS for crustacean trophic guilds; (a): shelf species; (b) slope species.

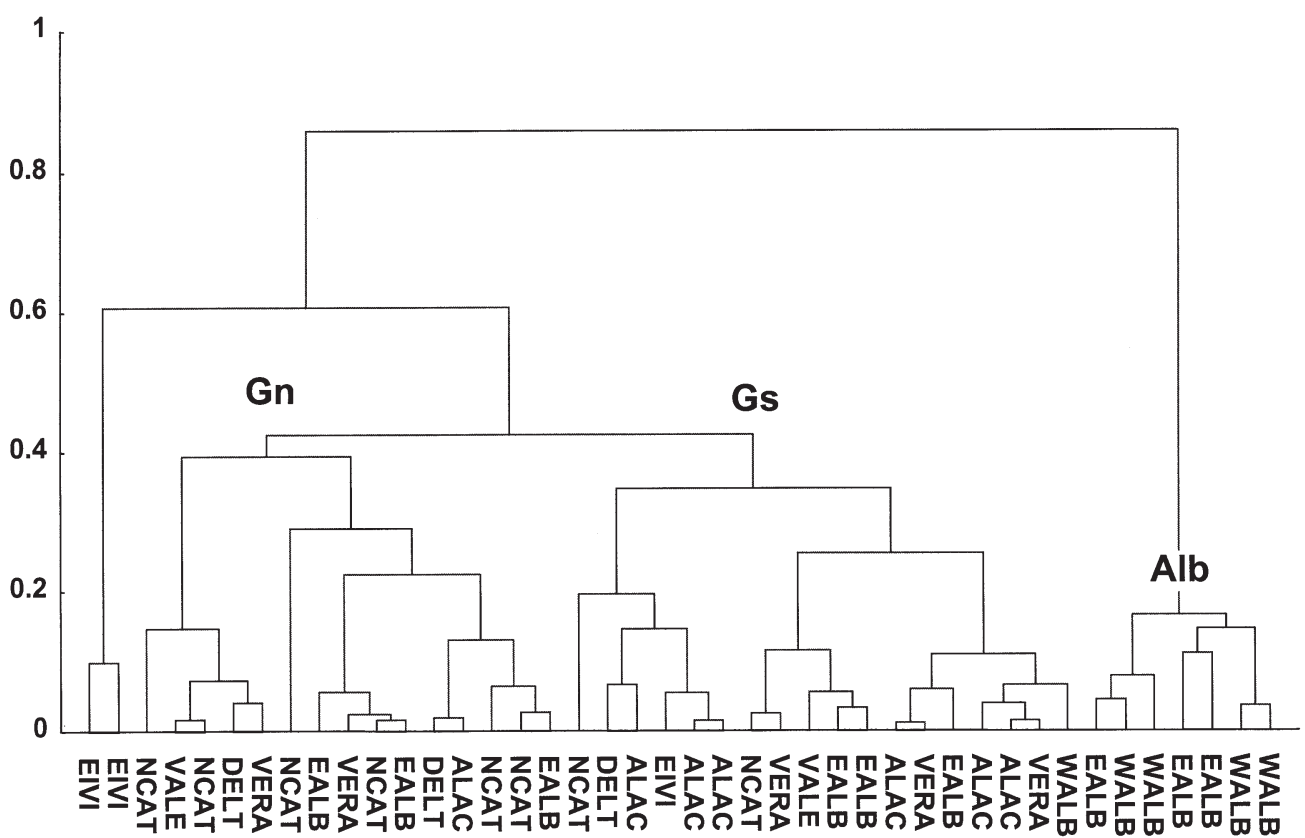

FIG. 5. - Cluster for the trophic guilds of bathyal fish (1-r / UPGMA), showing the formation of groups for the Catalano-Balearic Basin (Gn), the Algerian Basin (Gs), and the Alborán Sea (Alb). 


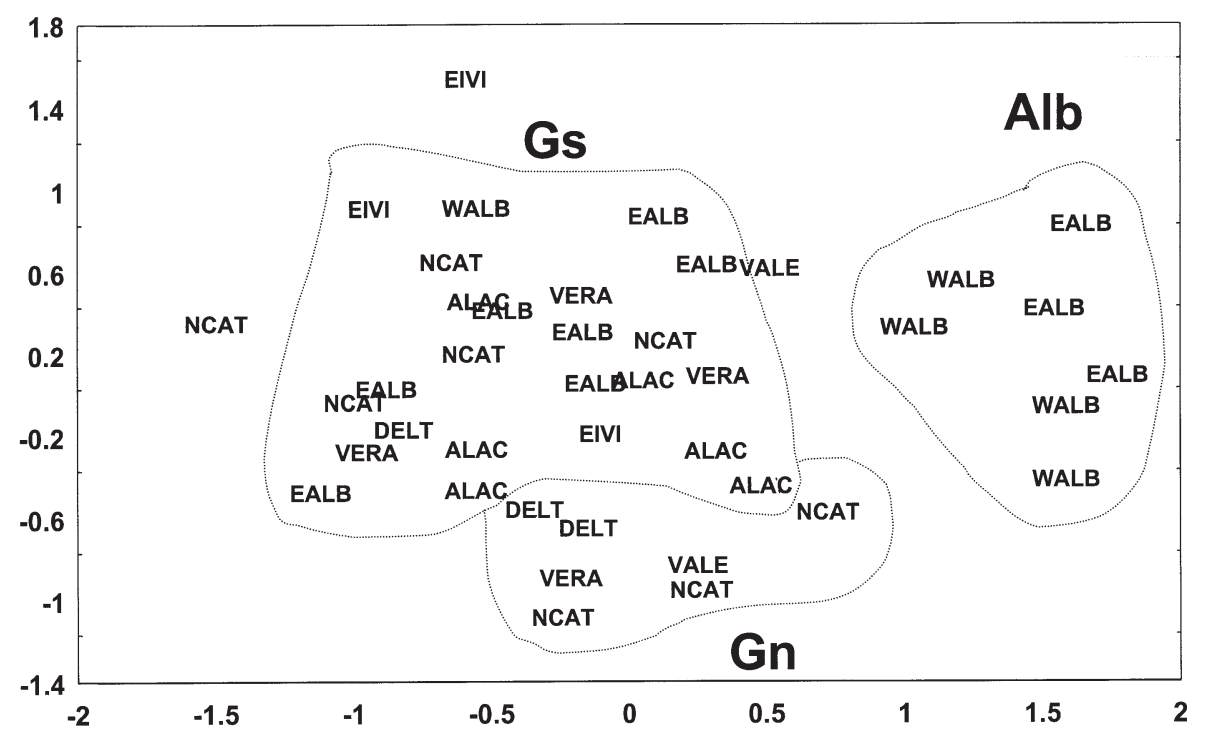

FIG. 6. - MDS analysis showing the distribution of groups of samples for the Catalano-Balearic Basin (Gn), the Algerian Basin (Gs), and the Alborán Sea (Alb).

performed in the Alborán Sea (Alb) which were dissimilar $(1-r=0.84)$ from the rest of samples. Some new groupings were also detected between trawls performed north and south from Cape La Nao (Fig. 5). Gs included 18 trawls, 15 of them performed south from Cape La Nao, whereas Gn included 15 trawls, 10 of them collected in the Catalano-Balearic Basin, north from Cape La Nao. Furthermore, the fact that some samples collected in a same sector (i.e NCAT, WALB, EIVI....) were further grouped, suggested small-scale or local spatial trends in the changes and distribution of trophic guilds. The MDS (stress $=0.150)$ separated the Alb group of seven samples (Fig. 6) from the rest. Within this last group, Gs, containing most of the samples from VERA, ALAC sectors, and also samples from EALB not included in the Alb group, can be identified in the top of Axis 2. The Gn group (Axis 2: bottom) is characterized by the dominance of samples

TABLE 3. - Abundance (ind/h) and percentage of the different trophic guilds for crustaceans obtained from cluster analysis. n: number of samples.

\begin{tabular}{|c|c|c|c|c|c|}
\hline & $\begin{array}{r}\text { shelf } \\
\mathrm{n}=44 \\
\text { ind./h }\end{array}$ & $(\%)$ & & $\begin{array}{c}\text { slope } \\
\mathrm{n}=42 \\
\text { ind./h }\end{array}$ & $(\%)$ \\
\hline $\mathrm{nmM}$ & 56.3 & 54.8 & $\mathrm{mM}$ & 671.3 & 55.9 \\
\hline EpB & 25.7 & 25.0 & $\mathrm{nmM}$ & 360.1 & 30.0 \\
\hline InfB & 11.2 & 10.9 & InfB & 113.2 & 9.4 \\
\hline Sca & 6.9 & 6.7 & Sca & 13.4 & 1.1 \\
\hline $\mathrm{mM}$ & 0 & 0 & EpB & 9.4 & 0.8 \\
\hline TOTAL & 101.1 & & & 1167.4 & \\
\hline
\end{tabular}

from VALE, DELT, and NCAT sectors and the total absence of EALB-WALB samples. It is interesting to compare the MDS results obtained for bathyal crustaceans and fish (Figs. 4b and 6), with a clearer geographical gradient detected among bathyal fish with some differences in the composition of guilds north and south from Cape La Nao.

The composition of trophic guilds for crustaceans has been detailed in Table 3. On the continental shelf, crustacean assemblages were dominated by non-migrator macroplankton feeders $(\mathrm{nmM}$; $54.8 \%$ ), and by epibenthos feeders (Epi; 25.0\%), both accumulating $c a$. $80 \%$ of abundance. The pandalid shrimps Plesionika heterocarpus and Chlorotocus crassicornis were the dominant species among $\mathrm{nmM}$, while portunid crabs (Liocarcinus depurator and Macropipus tuberculatus) dominated among Epi. On the slope (>300 $\mathrm{m}$ depth), migrator macroplankton feeders $(\mathrm{mM})$, and non-migrator macroplankton feeders (nmM), dominated accumulating $c a$. $86 \%$ of abundance (Table 3). Pasiphaea sivado and Sergestes arcticus dominated among the $\mathrm{mM}$, and Plesionika spp. among the nmM. Infaunal feeders (Inf; i.e. Parapenaeus longirostris and Aristeus antennatus) also reached some importance at this level (9.4\%).

Bathyal-fish assemblages were dominated by non-migrator macroplankton feeders $(\mathrm{nmM})$ and infaunal feeders (Inf), accumulating $\mathrm{ca}$. $70 \%$ of abundance (Table 4). The dominant species were the shark Galeus melastomus, the bony fish Gadiculus argenteus and Hoplostethus mediterraneus among 
TABLE 4. - Abundance (ind/h) and percentage of the different trophic guilds among bathyal fish by geographical area, obtained from cluster and MDS analysis. *Algerian Basin excluding the Alborán Sea area. n: number of samples.

\begin{tabular}{|c|c|c|c|c|c|c|c|c|}
\hline \multicolumn{3}{|c|}{$\begin{array}{l}\begin{array}{l}\text { Catalano-Balearic Basin } \\
\mathrm{n}=12\end{array}\end{array}$} & \multicolumn{3}{|c|}{$\underset{n=15}{\text { Algerian Basin* }}$} & \multicolumn{3}{|c|}{$\begin{array}{c}\text { Alborán Sea } \\
n=7\end{array}$} \\
\hline $\operatorname{infB}$ & 106.2 & 47.5 & $\mathrm{nmM}$ & 184.8 & 43.8 & $\mathrm{nmM}$ & 309.9 & 50.0 \\
\hline $\mathrm{mM}$ & 81.5 & 36.5 & $\mathrm{mM}$ & 125.7 & 29.8 & $\mathrm{vB}$ & 188.7 & 30.4 \\
\hline $\mathrm{nmM}$ & 20.2 & 9.0 & infB & 85.1 & 20.2 & infB & 60.4 & 9.7 \\
\hline vB & 9.7 & 4.3 & $\mathrm{vB}$ & 17.8 & 4.2 & EpB & 35.6 & 5.7 \\
\hline EpB & 3.0 & 1.3 & EpB & 4.1 & 1.0 & $\mathrm{mM}$ & 22.7 & 3.7 \\
\hline TOTAL & 220.6 & & & 422.5 & & & 617.3 & \\
\hline
\end{tabular}

$\mathrm{nmM}$, and Phycis blennoides and Coelorhynchus coelorhynchus within the Inf group. Geographical changes detected in trophic guilds among fish consisted in a higher percentage of abundance of Inf group in the Catalano-Balearic Basin (47.5\%), while $\mathrm{nmM}$ were dominant in G2 (Algerian Basin south of La Nao cape; $43.8 \%$ ) and in the Alborán Sea group (50\%) (Table 4). One-way ANOVAs and post-hoc Scheffé test indicated higher significant differences in the mean density (ind./h; $\mathrm{n}=42$ ) of some trophic guilds between the three geographical areas obtained from multivariate analysis of bathyal fish. The density of the $\mathrm{mM}$ guild in the Alborán Sea (Alb) was significantly higher than in the Algerian Basin $(\mathrm{AB})$ and in the Catalano-Balearic Basin $(\mathrm{CBB})(\mathrm{p}<0.05)$, while the density of $\mathrm{nmM}$ feeders was only significant between $\mathrm{Alb}$ and $\mathrm{CBB}$ $(\mathrm{p}<0.01)$. The density of the NS guild in the Alborán Sea (Alb) was also significantly higher than in the Algerian Basin $(\mathrm{AB})$ and in the Catalano-Balearic Basin $(\mathrm{CBB})(\mathrm{p}<0.001)$. Between the $A B$ and the $\mathrm{CBB}$ significant differences were only recorded comparing the density of the $\mathrm{mM}$ guild $(\mathrm{p}<0.05)$.

\section{DISCUSSION}

Analysis of feeding guilds may show differences in trophic structure and ecosystem dynamics, and therefore may have implications for the management of fisheries (Koslow, 1997). Along the coasts of the Iberian Peninsula, fish and crustacean communities exhibited different trophic structures depending not only on the taxa considered, but also on the depth of occurrence (shelf and slope assemblages), and on a geographical gradient. Shelf crustacean guilds prey more on benthos $(42 \%)$ than bathyal crustacean guilds (11\%), while zooplankton resources were more consumed by bathyal crustaceans $(86 \%)$ than by shelf species $(55 \%)$. Crus- taceans, however, are a secondary taxa in shelf communities (mean density: $100.1 \mathrm{ind} / \mathrm{h}$ ), where fishes widely dominate (mean density: $1604 \mathrm{ind} / \mathrm{h}$ ). As in the case of crustaceans, bathyal fish assemblages are also dominated by zooplanktophagous species $(61.4 \%)$ with some geographical variations (see below). The dominant shelf species were Capros aper, Maurolicus muelleri or small Merluccius merluccius (see Table 5) which also are well-natatory species preying on plankton resources (Macpherson, 1977; Withehead et al., 1986), attaining similar dominance ( $>68.5 \%$ of abundance) as that of bathyal fishes. These species are among the dominant fish in previous samplings conducted in the same area (Lloris et al., 2000).

Considering fish and crustaceans together, the plankton/benthos consumer ratio would be situated $\sim 2.3 / 1$ on the continental shelf, increasing to $\sim 4 / 1$ at the slope, which suggests a higher dependence on pelagic trophic resources by bathyal communities. These results are generally consistent with the available data both on the distribution of zooplankton and macrobenthos (available prey) on the shelf and slope in the study area. Thus, Sabatés et al. (1989) reported a major density of zooplankton offshore in the

TABLE 5. - Main fish species caught from shelf depths ordered by decreasing order of abundance (ind/h) during the MEDITS-99 survey. \%D: percentage of density.

\begin{tabular}{lrr}
\hline Species & D(ind./h) & $\% \mathrm{D}$ \\
\hline & & \\
Capros aper & 296.5 & 18.5 \\
Maurolicus muelleri & 230.2 & 14.4 \\
Merluccius merluccius & 186.1 & 11.6 \\
Cristallogobius linearis & 136.1 & 8.5 \\
Trachurus trachurus & 105.8 & 6.6 \\
Sardina pilchardus & 99.8 & 6.2 \\
Trisopterus minutus capelanus & 67.0 & 4.2 \\
Macroramphosus scolopax & 45.7 & 2.8 \\
Boops boops & 45.1 & 2.8 \\
Spicara smaris & 40.5 & 2.5 \\
& & \\
TOTAL & 1603.5 & 78.1 \\
\hline
\end{tabular}


shelf-slope break, associated with the permanent thermohaline front in the Catalan Sea area (Catalano-Balearic Basin). Similar frontal systems are also described in the mainland margins of the Algerian Basin (Millot, 1987). In contrast, benthos resources had higher importance as food-source in shelf communities, which is also consistent with a generally recognised decrease in benthos biomass with depth (Rowe, 1983). In the western Mediterranean, biomass and diversity of megafaunal invertebrates, such as echinoderms, were higher on the shelf (Pérès, 1985), a fact that was also observed in the present sampling (pers. obs.). In the CatalanoBalearic Basin, macrofaunal benthos biomass is $2.04 \mathrm{gAFDW} / \mathrm{m}^{2}$ at shelf depths (Guille, 1971), decreasing to $0.37 \mathrm{gDW} / \mathrm{m}^{2}$ at bathyal depths (400$600 \mathrm{~m}$ ) off Barcelona (authors unpubl. data).

Trophic guilds are widely defined and employed in macrobenthos studies (i.e. polychaetes: Fauchald and Jumars, 1979). Although this concept is less used in megafaunal studies, some authors also defined trophic guilds for fish (Gartner et al., 1997) using also equivalent functional feeding terms, such as trophic groups (Cartes, 1998) or feeding associations (Macpherson and Roel, 1987) both for fish and for large decapod crustaceans. The fact of including a species within a concrete feeding group or guild may be submitted to some criticisms since fish (and decapods) are euryphagous with a mixed diet, mainly, but not strictly, based on benthos or plankton prey (Macpherson and Roel, 1987; Mauchline and Gordon, 1991; Cartes, 1998). Furthermore, even in a relatively stable environment such as the deep sea, fish and invertebrates have changes in diet depending on size and season (Macpherson and Roel 1987; Cartes, 1994; 1998).

Our study has basically a comparative value, since the MEDITS-99 cruise was performed in MayJune, the period after the peak of primary production when a higher plankton biomass is available, thus probably biassing the diet of fish and crustaceans. We also assume that feeding preferences of species do not vary along the geographic gradient covered, this seeming reasonable when comparing the diet of some representative species from distant geographical areas. Thus, the red shrimp Aristeus antennatus preys mainly on polychaetes, bivalves and small peracarid crustaceans in the Catalan Sea (Cartes, 1994), in the Ligurian Sea (Relini Orsi and Würtz, 1977), and on the Atlantic coast of Morocco (Lagardère, 1972). A similar case is that of the shrimp Aristeomorpha foliacea which has a similar diet, based on pandalid shrimps and euphausiids, off the Balearic Islands (Cartes, 1995), off Morrocco (Lagardère, 1972) and also probably in Australian waters, where this shrimp preys on midwater crustaceans (Rainer, 1992). The Norway lobster Nephrops norvegicus preys on similar resources (polychaetes, decapod crustaceans and fish) at bathyal depths in the Bay of Biscay (Lagardère, 1977) and in the deep-Mediterranean (Cristo and Cartes, 1998; unpubl. data), with small changes only among secondary prey. Among fishes, bathyal species such as Helicolenus dactylopterus or vicariant Merluccius spp. (among many others) also have similar diets, concerning feeding guilds, in the western Mediterranean and off Namibia (Macpherson, 1977; Macpherson and Roel, 1987). There are numerous similar examples, not only restricted to commercial species (cf. Cartes, 1991, 1995), which generally support the assumption that feeding preferences of species do not vary along their geographical distribution covering similar habitats, particularly at bathyal environments.

Along the geographical gradient covered in this study, fish showed the most clear variations in trophodynamics in contrast to the almost non-existent changes detected for crustaceans. A latitudinal gradient on the trophic structure of marine ecosystems has already been cited, with energy flow being distinctly partitioned between benthos/plankton production from subarctic to tropical waters, thus supporting more demersal or pelagic fisheries (Petersen and Curtis, 1980). At our spatial scale, similar trends seem to occur only within bathyal fish assemblages, with an increase in macroplankton feeders in the Algerian Basin (southern Cape La Nao). Among crustaceans, distinct trophic guild composition has been detected previously comparing bathyal assemblages off the Catalan Sea and the SW Balearic Islands (off Eivissa), with higher dominance of the non-migrator macroplankton feeders (maily composed by Plesionika spp.) off the SW Balearic Islands, and infaunal and deposit feeders in the Catalan Sea (Cartes et al., in press). These changes were probably not observed here because none of the Iberian coast sectors sampled have the characteristics of an open-sea area (i.e low river discharges, absence of large submarine canyons....) occurring in the SW Balearic Islands.

Changes in the trophic structure detected among fish, may probably be related to their higher trophic level (TL) in comparison to decapods. Further to dietary studies which confirm that large fish (i.e 
sharks, Mora moro, M. merluccius) prey on decapods, thus occupying a higher TL (i.e. Carrasson et al., 1992), recent data on $\delta^{15} \mathrm{~N}$ stable isotopic composition confirm this same trend (Polunin et al., in press). Rex (1977) postulated more rapid changes in marine species substitution with depth with increasing trophic level, a hypothesis that has also been documented among deep-sea decapod crustaceans (Cartes, 1998). An extrapolation of this hypothesis at a "horizontal" spatial scale may explain why only fish, situated in a higher TL than decapods, showed geographical changes in the composition of their trophic guilds. Changes in deepdemersal fish communities at similar spatial scales as ours have been already documented off New Zealand (McClatchie et al., 1997), correlated to regional changes in surface phytoplankton production, while bottom subtratum is also important in the distribution of continental shelf and upper slope fish assemblages off the Catalan coasts (Demestre et al., 2000). The Alborán Sea has an unusual high primary production in comparison to other neighbouring Mediterranean areas, as can be observed based on satellite imagery. This feature may support a similar conclusion to that discussed for deep fish communities off New Zealand (McClatchie et al., 1997).

In summary, in the present study we have shown the following trends in the trophodynamics of the megafaunal assemblages along the coasts of the Iberian Peninsula depending on depth, taxa and the geographical gradient: 1) crustaceans (mainly decapods) have different trophic structure on the shelf and on the slope; 2) on the slope, fish exhibited clearer changes as a function of the geographical gradient than crustaceans; and 3) trophodynamics of bathyal fish showed some geographical variations between the Alborán Sea, the Catalano-Balearic Basin, and the Algerian Basin (basically VERAALAC sectors), with a progressive north-south increase in planktophagous species. More detailed and smaller spatial-scale studies on these trends (and their possible causes) may confirm whether the future management of these ecosystems should be considered under the depth and geographical strata here suggested.

\section{ACKNOWLEDGEMENTS}

We wish to thank all participants in the MEDITS-ES 99 cruise on board R/V "Cornide de Saavedra" for all their help and support.

\section{REFERENCES}

Abelló, P., A. Carbonell and P. Torres. - 2002. Biogeography of epibenthic crustaceans on the shelf and upper slope off the Iberian Peninsula Mediterranean coasts: implications for the establishment of natural management areas. Sci. Mar., 66 (Suppl. 2): 183-198.

Abelló, P., A. Carbonell, P. Torres and L. Gil de Sola. - 2000. Bathymetric and geographical variability in the characteristics of a population of Nephrops norvegicus (Crustacea: Decapoda) off the Iberian peninsula (western Mediterranean). In: J.A. Bertrand and G. Relini (eds.), Demersal resources in the Mediterranean, Proceedings of the Symposium held in Pisa, 1821 March 1998, Actes de Colloques 26, pp. 186-195. IFREMER, Plouzané.

Atkinson, D.B. - 1994. The biology and fishery of roundnose grenadier (Coryphaenoides rupestris, Gunnerus, 1765) in the North West Altalntic. In: Hopper, A.G. (ed.).Deep-water fisheries of the North Atlantic slope: Kluwer Academic Publishers. Dordrecht. p. 51-112.

Bas, C., E. Morales and M. Rubió. - 1955. La Pesca en España, I Cataluña. Instituto de Investigaciones Pesqueras. Barcelona.

Bertrand, J.A., L. Gil de Sola, C. Papaconstantinou, G. Relini and A. Souplet. - 2000. An international bottom trawl survey in the Mediterranean: the MEDITS programme. In: J.A. Bertrand and G. Relini (eds.), Demersal resources in the Mediterranean, Proceedings of the Symposium held in Pisa, 18-21 March 1998, Actes de Colloques 26, pp. 76-93. IFREMER, Plouzané.

Bertrand, J.A. and G.Relini. - 2000. Demersal Resources in the Mediterranean. IFREMER, Plouzané.

Bowering, W.R. and W.B. Brodie. - 1994. Greenland halibut (Reinhardtius hippoglossoides). A review of the dynamics of its distribution and fisheries off Eastern Canada and Greenland. In: Hopper, A.G. (ed.).Deep-water fisheries of the North Atlantic slope: Kluwer Academic Publishers. Dordrecht. p. 113-160.

Bulman, C.M. and J.A. Koslow. - 1992. Diet and food consumption of a deep-sea fish, orange roughy Hoplostethus atlanticus (Pisces: Trachichthydae), off southeastern Australia. Mar. Ecol. Prog. Ser., 82: 115-129.

Carbonell, A., P. Abelló, P. Torres and L. Gil de Sola. - 2000. Distribution and abundance of Aristeus antennatus (Decapoda: Dendrobranchiata) along the Mediterranean Spanish coast. In: J.A. Bertrand and G. Relini (eds.), Demersal resources in the Mediterranean, Proceedings of the Symposium held in Pisa, 1821 March 1998, Actes de Colloques 26, pp. 165-172. IFREMER, Plouzané.

Carrasson, M. - 1994. Relaciones tróficas en las comunidades ícticas bentónicas (de 1000 a $2200 \mathrm{~m}$ ) en el Mar Catalán. Tesis Doctoral. Universidad Autónoma de Barcelona.

Carrasson, M., and J. Matallanas. - 1990. Preliminary data about the feeding habits of some deep-sea Mediterranean fishes. $J$. Fish. Biol., 36: 461-463.

Carrasson, M., J. Matallanas and M. Casadevall. - 1998. Feeding strategies of deep-water morids on the Western Mediterranean. Deep-Sea Res I, 44: 1685-1700.

Carrasson, M., C. Stefanescu and J.E. Cartes. - 1992. Diets and bathymetric distributions of two bathyal sharks of the Catalan deep-sea (Western Mediterranean). Mar. Ecol. Prog. Ser., 82: 21-30.

Cartes, J.E. - 1991. Análisis de las comunidades y estructura trófica de los crustáceos decápodos batiales del Mar Catalán. Tesis doctoral. Universitat Politècnica de Catalunya. 627 pp.

Cartes, J.E. - 1994. Influence of depth and seasonality in the diet of the deep-water shrimp Aristeus antennatus along the slope (between 400 - 2300 m). Mar. Biol., 120: 639-648.

Cartes, J.E. - 1995. Diets of, and trophic resources exploited by, bathyal Penaeoidean shrimps from the western Mediterranean. Mar. Fresh. Res., 46: 889-896.

Cartes, J.E. - 1998. Feeding strategies and partition of food resources in deep-water decapod crustaceans in relation to depth (between 400-2300 m). J. Mar. Biol. Ass. U.K., 78: 509-524.

Cartes, J.E. and P. Abelló. - 1992. Comparative feeding habits of Polychelid lobsters in the western Mediterranean. Mar. Ecol. Prog. Ser., 84: 139-150.

Cartes, J.E., M. Elizalde and J.C. Sorbe. - 2000. Contrasting life-histories and secondary production of populations of Munnopsurus atlanticus (Isopoda Asellota) from two bathyal areas of the NE Atlantic and the NW Mediterranean. Mar. Biol., 136: 881-890. 
Cartes, J.E. and F. Maynou. - 1998. Food consumption by bathyal decapod crustacean assemblages in the western Mediterranean: An approach to predatory impact and to a food consumptionfood supply balance in a deep-water food web. Mar. Ecol. Prog. Ser., 171: 233-246.

Cartes, J.E. and F. Maynou. - 2001. Trophodynamics of Boreomysis arctica, a deep-water dominant mysid from the suprabenthic community of the Catalan Sea (western Mediterranean). Mar. Ecol. Prog. Ser., 221: 225-234.

Cartes, J.E., F. Maynou, B. Morales-Nin, E. Massutí and J. Moranta.- 2001. Trophic structure of a bathyal benthopelagic boundary layer community south of the Balearic Islands (southwestern Mediterranean). Mar. Ecol. Prog. Ser., 215:23-35.

Cartes, J.E. and J.C. Sorbe. - 1999. Estimating secondary production in bathyal suprabenthic peracarid crustaceans from the Catalan Sea slope (western Mediterranean; 391-1255 m). J. exp. Mar. Biol. Ecol., 239: 195-210.

Christensen, V. - 1995. A model of trophic interactions in the North Sea in 1981, the year of stomach. Dana, 11: 1-28.

Cristo, M. and J.E. Cartes. - 1998. A comparative study of the feeding ecology of Nephrops norvegicus (L.) (Decapoda: Nephropidae) in the bathyal Mediterranean and adjacent Atlantic. Sci. Mar., 62: 81-90.

Demestre, M., P. Sánchez and P. Abelló. - 2000. Demersal fish assemblages and habitat characteristics on the continental shelf and upper slope of the north-western Mediterranean. J. Mar. Biol. Ass. U.K., 80: 981-988.

Fauchald, K. and P.A. Jumars. - 1979. The diet of worms: a study of polychaete feeding guilds. Oceanogr. Mar. Biol. Ann. Rev., 17: 193-284.

Gartner, J.V., R.E. Crabtree and K.J. Sulak. - 1997. The feeding ecology of deep-sea fishes. In: Randall, D.J. and A.P. Farrell (eds.). Deep-Sea Fishes: Academic Press. San Diego. p. 115-182.

Guille, A. - 1971. Bionomie benthique du plateau continentale de la côte catalane française. IV- Densités, biomasses et variations saisonnières de la macrofaune. Vie Milieu, 22: 93-158.

Haedrich, R.L., and N.R. Merrett. - 1990. Little evidence for faunal zonation or communities in deep sea demersal fish faunas. Progr. Oceanogr., 24: 239-250.

Hopper, A.G. - 1994. Deep-water fisheries of the North Atlantic Oceanic slope. NATO ASI Series. Kluwer Academic Publishers. Dordrecht.

Hutchings, J.A. and R.A. Myers. - 1994. What can be learned from the collapse of a renewable resource ? Atlantic cod, Gadus morhua, of Newfoundland and Labrador. Can. J. Fish. Aquat. Sci., 51: 2126-2146.

Jennings, S., O. Reñones, B. Morales-Nin, N.V.C. Polunin, J. Moranta and J. Coll. - 1997. Spatial variation in the ${ }^{15} \mathrm{~N}$ and ${ }^{13} \mathrm{C}$ stable isotope composition of plants, invertebrates and fishes on Mediterranean reefs: implications for the study of trophic pathways. Mar. Ecol. Prog. Ser., 146: 109-116.

Koslow, J.A. - 1997. Seamounts and the ecology of deep-sea fisheries. Am. Sci., 85: 168-176

Lagardère, J.P. - 1972. Recherches sur l'alimentation des Crevettes de la Pente Continentale Marocaine. Tethys, 3: 655-675.

Lagardère, J.P. - 1977. Recherches sur la distribution verticale et sur l'alimentation des crustacés decapodes benthiques de la pente continentale du Golfe de Gascogne. Analyse des groupements carcinologiques. Bull. Cent. Etud. Rech. sci. Biarritz, 11(4): $367-440$

Lloris, D., L. Gil de Sola and J. Rucabado. - 2000. Ichtyofauna caught during the MEDITS-ES cruises (1994 to 1997) in the western Mediterranean. In: J.A. Bertrand and G. Relini (eds.), Demersal resources in the Mediterranean, Proceedings of the Symposium held in Pisa, 18-21 March 1998, Actes de Colloques 26, pp. 221-228. IFREMER. Plouzané.

Macpherson, E. - 1977. Estudio sobre relaciones tróficas en peces bentónicos de la costa catalana. Tesis Doctoral. Universidad de Barcelona.

Macpherson, E. - 1979. Ecological overlap between Macrourids in the Western Mediterranean Sea. Mar. Biol., 53: 149-159.
Macpherson, E. - 1985. Daily ration and feeding periodicity of some fishes off the coast of Namibia. Mar. Ecol. Prog. Ser., 26: 253-260.

Macpherson, E. and B.A. Roel. - 1987. Trophic relationships in the demersal fish community off Namibia. S. Afr. J. mar. Sci., 5: 585-596.

Mauchline, J. and J.D.M. Gordon. - 1991. Oceanic pelagic prey of benthopelagic fish in the benthic boundary layer of a marginal oceanic region. Mar. Ecol. Prog. Ser., 74: 109-116.

Maynou, F. and J.E. Cartes. - 1997. Estimation of daily ration on field in the deep-sea shrimp Aristeus antennatus. Mar. Ecol. Prog. Ser., 153: 191-196.

Maynou, F. and J.E. Cartes. - 1998. Daily ration estimates and comparative study of food consumption in deep-water decapod crustacean of the NW Mediterranean Mar. Ecol. Prog. Ser., 171: 221-231.

Maynou, F. and J.E. Cartes. - 2000. Community structure of bathyal decapod crustacean assemblages off the Balearic Islands (south-western Mediterranean). J. Mar. Biol. Ass.U.K., 80: 789-798.

McClatchie S., R.B. Millar, F. Webster, P.J. Lester, R. Hurst and N. Bagley. - 1997. Demersal fish community diversity off New Zealand: Is it related to depth, latitude and regional surface phytoplankton? Deep-sea Res. I, 44: 647-667.

Merrett, N.R. and R.L. Haedrich. - 1997. Deep-sea demersal fish and fisheries. Chapman and Hall. London.

Millot, C. - 1987. Circulation in the western Mediterranean. Oceanol. Acta., 10: 143-149.

Pauly, D. and V. Christensen. - 1995. Primary production required to sustain global fisheries. Nature, 374: 255-257.

Pérès, J.M. - 1985. History of the Mediterranean biota and the colonization of the depths. In: Margalef, R. (ed.) Key Environments: Western Mediterranean. Pergamon Press. New York. pp. 198-232.

Petersen, G.H. and M.A. Curtis. - 1980. Differences in the energy flow through major components of subartic, temperate and tropical marine shelf ecosystems. Dana, 1: 53-64.

Polunin, N.V.C., B. Morales-Nin, W.E. Pawsey, J.E. Cartes, J.K. Pinnegar and J. Moranta.- 2001. Feeding relationships in Mediterranean bathyal assemblages elucidated by carbon and nitrogen stable-isotope data. Mar. Ecol. Prog. Ser., 220: 13-23.

Rainer, S.F . - 1992. Diet of prawn from the continental slope of north-western Australia. Bull. Mar. Sci., 50: 258-274.

Relini Orsi, L. and M. Würtz. - 1977. Aspetti della rete trofica batiale riguardanti Aristeus antennatus (Risso, 1816)(Crustacea, Penaeidae). Atti IX Cong. Soc. Ital. Biol. Marina. Ischia. pp. 389-398.

Rex, M.A. - 1977. Zonation in deep-sea gastropods: the importance of biological interactions to rates of zonation. In: Keegan, B.F. P.O. Ceidigh and P.J.S. Boaden (eds.). Pergamon Press. New York. pp. 521-530.

Robinson, C.L.K., and D. Ware. - 1994. Modelling pelagic fish and plankton trophodynamics off Southwestern Vancouver Island, British Columbia. Can. J. Fish. Aq. Sci., 51: 1737-1750.

Rowe, G.T. - 1983. Biomass and production of the Deep-sea Macrobenthos. In: Rowe, G.T. (ed.) Deep-Sea Biology: The Sea, Vol. 8. John Wiley and Sons. New York. pp. 97-121.

Sabatés, A., J.M. Gili and F. Pagés. - 1989. Relationship between zooplankton distribution, geographic characteristics and hydrodynamic patterns off the Catalan coast (Western Mediterranean). Mar. Biol., 103: 153-159.

Stefanescu, C. and J.E. Cartes. - 1992. Benthopelagic habits of adult specimens of Lampanyctus crocodilus (Risso, 1810) (Osteichthyes, Myctophidae) in the western Mediterranean deep slope. Sci. Mar., 56: 69-74.

Withehead, P.J.P, M.L. Bauchot, J.C. Hureau, J. Nielsen and E. Tortonese. - 1986. Fishes of the North-eastern Atlantic and the Mediterranean. UNESCO. R. Clay Ltd. Bungay.

Wolff, M. - 1994. A trophic model for Tongoy Bay - a system exposed to suspended scallop culture (Northern Chile). J. exp. Mar. Biol. Ecol., 182: 149-168. 